10.53116/pgaflr.2020.1.3

\title{
The Influence of EU Law on Public Administration in New Member States
}

\author{
Radomír Jakab* \\ * JUDr. Radomír Jakab, PhD, Associate Professor of Administrative Law and Sciences, Faculty of \\ Law, Pavol Jozef Šafárik University in Košice, Slovakia, email: radomir.jakab@upjs.sk, ORCID: \\ https://orcid.org/0000-0003-2074-8676
}

\begin{abstract}
The membership of Central and Eastern European countries in the European Union has influenced the development of almost all branches of law, including administrative law. The paper analyses the influence of European Union law on the fundamental object of interest of administrative law within new member states - on public administration and its laws. In this context, the influence on laws governing the organisation of public administration, laws governing the activities and tasks of public administration as well as laws governing processes in public administration will be assessed.
\end{abstract}

Keywords: European Union, public administration, processes in public administration, extraterritoriality, transterritoriality

\section{Introduction}

Following the Luxembourg Summit of December 1997, the European Union was involved in a process of preparing the most ambitious enlargement ever: thirteen countries, with economic structures, histories and cultures different from those of the other $15 \mathrm{EU}$ states, had applied for membership. These were: Bulgaria, Cyprus, the Czech Republic, Estonia, Hungary, Latvia, Lithuania, Malta, Poland, Romania, Slovakia, Slovenia and Turkey. These states had been applicant counties for quite some time, but the enlargement process was lengthy and cumbersome (Zervoyianni et al., 2006, pp. 34-35).

The Slovak Republic, the Czech Republic, the Republic of Poland and Hungary (hereinafter referred to as the "V4 countries"), as well as Malta, Cyprus, Slovenia, Estonia, Latvia and Lithuania have been Member States of the European Union since 1 May 2004. Bulgaria and Romania have become Member States of the European Union since 1 January 2007, and Croatia since 1 July 2013.

The membership in this transnational organisation entails the need for adapting national law to the requirements of this organisation in various areas (Schweiger \& Visvizi, 2018 , p. 120). However, this process of adapting national law had begun before these countries became members of the European Union, in the context of meeting the preaccession criteria, the so-called Copenhagen criteria (see Brusis, 2002, p. 49). The political and institutional criteria were: i) protection of human rights and respect for minorities, ii) fight against organised crime, drugs and illegal migration, iii) protection of the environment, iv) adoption of the aims of the EU and ability to enforce the EU legislation, and v) ability to pay the contributions to the EU budget on a regular basis. The economic criteria 
were: i) creation of the well-functioning market economy, and ii) ability to cope with the competitive pressures within the EU (see also Füle, 2013, pp. 9-12).

Adapting national law to the requirements of the European Union covers almost all branches of law, including administrative law. Indeed, it can be stated that this branch of law must reflect "European trends" to the greatest extent. The influence of European Union law can be seen in relation to laws governing the organisation of public administration, laws governing processes in public administration, and, to the greatest extent, laws governing the tasks and activities of public administration (see e.g. Hofmann et al., 2011, p. 259).

The aim of this paper is to analyse how and to what extent European Union law has influenced the above mentioned branches, i.e. laws governing the organisation of public administration in the new Member States, laws governing the activities of public administration in these countries, as well as laws governing processes in public administration of the new Member states. Given the broad focus of this paper, its aim is not to provide a detailed and exhaustive enumeration of these influences, but above all to point out, the most fundamental of them in the author's view. Its purpose is to open a discussion on the issue as part of efforts to develop educational and scientific cooperation between academics from new Member states.

Taking into consideration the aim of this paper, it was necessary to apply mainly standard methods of research. First of all, it was necessary to analyse the current state of regulation in defined areas of public administration and to identify areas affected by European Union law. These areas had to be compared to the regulation in the new Member States. Based on this analysis and comparison, it was necessary to aggregate conclusions on the manner and extent of the impact of European Union law on the given areas of public administration.

\section{The influence of European Union law on laws governing the organisation of public administration}

The organisation of public administration is a complex, internally structured system consisting of various interconnected subsystems. Based on the organisational understanding of public administration, we can characterise public administration as a formal institution or set of institutions. Each formal institution is characterised, in particular, by its organisational structure, procedural rules and mutual communication system. Their purpose is to ensure the implementation of stipulated objectives based on the principle of maximum efficiency of its work. In individual countries, the organisation of public administration is implemented in various forms. It is mainly influenced by historical traditions, the size of the territory of the country, a period of time usually associated with the reform of public administration, in a certain developmental stage of the country, and so on (Sobihard, 2007, p. 81).

In addition to the factors mentioned above, the organisation of public administration in a given country may be influenced by membership in transnational and international 
organisations. Within the European area, the Council of Europe and the European Union are of particular relevance in this regard.

The Council of Europe, through its acts, either international treaties concluded under its auspices ${ }^{1}$ or resolutions and recommendations of the Committee of Ministers ${ }^{2}$, lays down, as a rule, the qualitative requirements for public administration activities, and defines the basic rules and principles in public administration activities and procedures (see Košičiarová, 2012). However, it does not directly lay down requirements for the organisation of public administration, the institutional framework of public administration authorities in a member state of the Council of Europe. This influence is only indirect, and concerns the establishment of the organisational basis of public administration in order to optimise the implementation of the above mentioned quality rules and principles related to the activities of public administration (see Addink, 2005, pp. 21-43).

The situation is similar in relation to the influence of the European Union and its law on the organisation of public administration. Thus, this transnational organisation also lays down certain rules and principles to be applied in the activities of the Member States; it is reflected in the organisation of public administration only indirectly.

One such principle is the principle of sincere cooperation, arising from Article 4(3) of the Treaty on European Union. "Pursuant to the principle of sincere cooperation, the Union and the Member States shall, in mutual respect, assist each other in carrying out tasks which flow from the Treaties." 3 The principle of sincere cooperation also involves a requirement applicable to the Member States to provide a sufficient institutional framework for carrying out tasks arising from the primary and/or secondary acts of European Union law.

A similar conclusion can also be drawn from Article 197 of the Treaty on the Functioning of the European Union (Pekár, 2012, p. 86). According to this Article, "Effective implementation of Union law by the Member States, which is essential for the proper functioning of the Union, shall be regarded as a matter of common interest. The Union may support the efforts of Member States to improve their administrative capacity to implement Union law. Such action may include facilitating the exchange of information and of civil

\footnotetext{
For example, the European Charter of Local Self-Government.

2 For example, Resolution No (77) 31 of the Committee of Ministers of the Council of Europe on the protection of the individual in relation to the acts of administrative authorities, Recommendation No (80) 2 of the Committee of Ministers of the Council of Europe concerning the exercise of discretionary powers by administrative authorities, Recommendation No (87) 16 of the Committee of Ministers of the Council of Europe on administrative procedures affecting a large number of persons, Recommendation No (81) 19 of the Committee of Ministers of the Council of Europe on the access to information held by public authorities, Recommendation No (91) 10 of the Committee of Ministers of the Council of Europe on the communication to third parties of personal data held by public bodies, Recommendation No (2002) 2 of the Committee of Ministers of the Council of Europe on access to official documents, Recommendation No (84) 15 of the Committee of Ministers of the Council of Europe relating to public liability, Recommendation No (91) 1 of the Committee of Ministers of the Council of Europe on administrative sanctions, Recommendation No (2000) 10 of the Committee of Ministers of the Council of Europe on codes of conduct for public officials, Recommendation No (89) 8 of the Committee of Ministers of the Council of Europe on provisional court protection in administrative matters, Recommendation No (2003) 16 of the Committee of Ministers of the Council of Europe on the execution of administrative and judicial decisions in the field of administrative law, Recommendation No (2004) 20 of the Committee of Ministers of the Council of Europe on judicial review of administrative acts, Recommendation No (2007) 7 of the Committee of Ministers of the Council of Europe on good administration.

3 Article 4(3) of the Treaty on European Union.
} 
servants as well as supporting training schemes. No Member State shall be obliged to avail itself of such support. The European Parliament and the Council, acting by means of regulations in accordance with the ordinary legislative procedure, shall establish the necessary measures to this end, excluding any harmonisation of the laws and regulations of the Member States. This Article shall be without prejudice to the obligations of the Member States to implement Union law or to the prerogatives and duties of the Commission. It shall also be without prejudice to other provisions of the Treaties providing for administrative cooperation among the Member States and between them and the Union."

These general requirements for ensuring a sufficient administrative framework implementing European Union law in the territory of a Member State are subsequently specified in the acts of the secondary law of the European Union. Subsequently, these acts require the existence of authorities having a power to check compliance with specific obligations arising from acts of the European Union, as well as deciding in case of their breach.

For example, Article 5 of Directive No 2006/114/ES the European Parliament and of the Council of 12 December 2006 concerning misleading and comparative advertising requires Member States to confer upon courts or administrative authorities powers enabling them, in cases where they deem such measures to be necessary taking into account all the interests involved and in particular the public interest, to take measures for the cessation of, or to order the prohibition of publication of, misleading advertising or unlawful comparative advertising (see also Jakab, 2016, p. 20).

Generally speaking, it can be stated that European Union law lays down a requirement for Member States to ensure a sufficient framework of public administration authorities that will enforce compliance with the obligations arising (directly or indirectly) from acts of the European Union and ensure liability if they are breached. However, the European Union does not specify any requirements for the category, the position of such an authority in the system of organisation of public administration of a Member State, or for the organisation of public administration as such.

However, there are some exceptions to the statement in the previous paragraph. Specifically, European Union law implies the requirement for the creation of so-called national regulatory authorities exercising their competence, in particular, in relation to markets where competition is not sufficiently developed (in particular, network industries), or regulating Europe-wide issues (e.g. personal data protection, broadcasting and retransmission). In addition to the requirement for the existence of such authorities, European Union law also implies other requirements for their independence, their competence or procedural rules.

In the new Member States, this was reflected in the extension of the category of state administration authorities with nationwide competence independent of other public administration authorities, including central state administration authorities. Under the influence of European Union law, either after the accession of the new Member States to the European Union or in the process of approximation of law in the pre-accession period, several authorities of this category were created. Some examples, not exhaustive, of this category are provided below.

4 Article 197 of the Treaty on the Functioning of the European Union. 
The legal status of such authorities is influenced by Article 3 of Directive No 2002/21/ EC of the European Parliament and of the Council of 7 March 2002 on a common regulatory framework for electronic communications networks and services (Framework Directive). Under that Article, Member States shall "ensure that each of the tasks assigned to national regulatory authorities in this Directive and the Specific Directives is undertaken by a competent body. Member States shall guarantee the independence of national regulatory authorities by ensuring that they are legally distinct from and functionally independent of all organisations providing electronic communications networks, equipment or services. Member States that retain ownership or control of undertakings providing electronic communications networks and/or services shall ensure effective structural separation of the regulatory function from activities associated with ownership or control." Based on these requirements, such authorities as, for example, the Telecommunications Office of the Slovak Republic (Telekomunikačny úrad Slovenskej republiky) was established in the Slovak Republic; nowadays it is the Regulatory Office for Electronic Communications and Postal Services (Úrad pre reguláciu elektronických komunikácii a poštových služieb). In the Czech Republic, these requirements are fulfilled by the Czech Telecommunication Office (Český telekomunikačni úrad), in the Republic of Poland by the Office of Electronic Communications (Urzad Komunikacji Elektronicznej), or in Hungary by the National Media and Infocommunication Authority (Nemzeti Média-és Hirközlési Hatóság).

The creation of a national regulatory authority in the new Member States in the field of regulation of the market of electricity and gas, as well as in other network industries, also resulted from the requirements of European Union law. At present, the requirements for the position, powers and quality of this national regulatory authority are specified in Article 35 et seq. of Directive No 2009/72/EC of the European Parliament and of the Council of 13 July 2009 concerning common rules for the internal market in electricity and repealing Directive 2003/54/EC. The requirements of the Directive in relation to such an authority include: the requirement for the creation of one national regulatory authority, the requirement for the independence of such an authority that exercises its powers impartially and transparently (is legally distinct and functionally independent of any other entity, acts independently of any market interests, does not seek or take instructions from other authorities), the requirement for an independent budget, the requirement for the term of office of the chairman (5-7 years), or the exact specification of the objectives, duties and powers of such an authority (Articles 36, 37). In order to meet the requirements of European Union law, an independent Public Utilities Commision (Sabiedrisko pakalpojumu regulēśanas komisija) was established in Latvia, the Energy Regulatory Authority (Nationalacde Reglementari in domeniul Energiei) in Romania, the Energy Agency (Agencija za energijo) in Slovenia, or the Estonian Competition Authority (Konkurentsiamet) in Estonia.

A national regulatory authority for personal data protection also belongs to the category of state administration authorities with nation-wide competence whose creation is influenced by European Union law. The requirement for the existence of such an authority stems from Article 51 et seq. of Regulation (EU) 2016/679 of the European Parliament and of the Council of 27 April 2016 on the protection of natural persons with regard to the processing of personal data and on the free movement of such data, and repealing 
Directive 95/46/EC (General Data Protection Regulation). Under Article 51 of that Regulation, "Each Member State shall provide for one or more independent public authorities to be responsible for monitoring the application of this Regulation, in order to protect the fundamental rights and freedoms of natural persons in relation to processing and to facilitate the free flow of personal data within the Union." In addition to the requirement for the existence of such a regulatory authority, the Regulation also lays down the requirement for independence (Article 52), the requirements for members (Article 53), the rules on establishment (Article 54), and the competence, tasks and powers of the national regulatory authority (Articles 55-58). Thus, European Union law regulates very intensively the nature and activities of such an authority. New Member States already created such national regulatory authorities under the influence of the previous legislation of the European Union, while in their current form they reflect the requirements of the above mentioned Regulation. The Office for Personal Data Protection of the Slovak Republic (Úrad na ochranu osobných údajov Slovenskej republiky) has been established in the Slovak Republic, the Croatian Personal Data Protection Agency (Agencija za zaśtitu osobnih podataka) in Croatia, the State Data Protection Inspectorate (Valstybiné duomenu Apsaugos Inspekcija) in Lithuania, or the Office of the Information and Data Protection Commissioner in Malta.

\section{Influence of European Union law on the activities of public administration}

The membership of new Member States in the European Union also influenced the type, scope, quantity and quality of tasks carried out by national public administration in these Member States. In addition to standard tasks carried out by public administration, the implementation of European Union law has also fallen to the scope of their tasks (see also Heidbreder \& Brandsma, 2017, p. 805-821).

In identifying tasks through which national public administration implements European Union law, it is first necessary to define the interface between tasks carried out directly by the bodies, institutions and agencies of the European Union and those carried out by national public administration, either alone or in cooperation with the bodies, institutions and agencies of the European Union. In this context, a reference should be made to the division of competences of the European Union. The Lisbon Treaty introduced four basic categories of competences of the European Union: exclusive competences, shared competences, supporting competences and special competences. European Union law does not enumerate particular competences of the Union, but only the areas of individual competences. In addition to explicit competences, i.e. competences expressly provided for in the founding Treaties, there are also implicit competences of the Union which may result from the provisions of the founding Treaties, as well as from acts adopted by the institutions of the Union (Jánošíková, 2013, p. 27).

In specifying the tasks of national public administration in the implementation of European Union law, it is necessary to specify which tasks are carried out exclusively by the European Union bodies, institutions and agencies, i.e. which tasks do not belong to the 
scope of activity of national public administration. It is the category of the so-called exclusive competence. Under Article 3(3) of the Treaty on the Functioning of the European Union, "the Union shall have exclusive competence in the following areas: (a) customs union; (b) establishing the competition rules necessary for the functioning of the internal market; (c) monetary policy for the Member States whose currency is the euro; (d) the conservation of marine biological resources under the common fisheries policy; (e) common commercial policy. The Union shall also have exclusive competence for the conclusion of an international agreement when its conclusion is provided for in a legislative act of the Union or is necessary to enable the Union to exercise its internal competence, or in so far as its conclusion may affect common rules or alter their scope" (see also Konstadinides, 2009, pp.151-152).

On the other hand, there is a category of the so-called shared competence, i.e. competence exercised by both the Union and the Member States, while the Member States exercise it only to the extent to which it is not exercised by the Union. ${ }^{5}$ Under Article 4(2) of the Treaty on the Functioning of the European Union, "shared competence between the Union and the Member States applies in the following principal areas: (a) internal market; (b) social policy, for the aspects defined in this Treaty; (c) economic, social and territorial cohesion; (d) agriculture and fisheries, excluding the conservation of marine biological resources; (e) environment; ( $f$ ) consumer protection; $(g$ ) transport; (b) trans-European networks; (i) energy; (j) area of freedom, security and justice; (k) common safety concerns in public health matters, for the aspects defined in this Treaty."

The room for implementing European Union law through national public administration can be seen, in particular, in the category of shared competence. First of all, the European Union regulates this competence, as a rule, in the form of directives. Therefore, Member States must implement these directives in national legislation. Subsequently, Member States, through their authorities, in particular, public authorities, implement this law and ensure that it complies.

Given a large set of tasks of national public administration in the implementation of European law, it is impossible to give their exhaustive list. With some degree of generalisation, it is possible to point out the most important ones, in which the influence of the European Union is noticeable. Taking into account the European Union's initial idea - the common internal market and the related free movement of persons, free movement of goods and free movement of capital -, the most notable tasks of national public administration influenced by European Union law are the following.

In the context of strengthening the free movement of persons, the tasks of national public administration have been influenced in particular in connection with foreigners' residence, employment services, conditions relating to the pursue of business activity (in particular, small business activity), other regulated activities, as well as services in the internal market. As regards the free movement of goods, the tasks of national public administration were most influenced. This was manifested mainly in connection with the liberalisation and deregulation of certain types of markets (energy, heating, postal services, water management, transport, etc.), consumer protection, food security, or with laying down the technical requirements for products, etc. Last but not least, the free movement

5 Article 2(2) of the Treaty on the Functioning of the European Union. 
of capital has necessitated interference in the activities and tasks of public administration of Member States, in particular as regards the harmonisation of laws governing banking, insurance and capital market.

The tasks of public administration of Member States are not only specified in the acts of general application of European law (or in national legislation implementing the above mentioned acts of the European Union), but can also be laid down in individual acts - decisions of the bodies, institutions or agencies of the European Union. These acts may also impose a duty on national administration to act in a certain way. For example, Article 108(2) of the Treaty on the Functioning of the European Union states: "If, after giving notice to the parties concerned to submit their comments, the Commission finds that aid granted by a State or through State resources is not compatible with the internal market having regard to Article 107, or that such aid is being misused, it shall decide that the State concerned shall abolish or alter such aid within a period of time to be determined by the Commission." This means that the Commission shall decide that the competent authority of a Member State shall act in a certain way.

A similar duty of a Member State to act is also defined in Article 299 of the Treaty on the Functioning of the European Union, i.e. the duty of a Member State to ensure the enforcement of a decision of the European Union body imposing a pecuniary obligation. Under that provision, "Acts of the Council, the Commission or the European Central Bank which impose a pecuniary obligation on persons other than States, shall be enforceable. Enforcement shall be governed by the rules of civil procedure in force in the State in the territory of which it is carried out. The order for its enforcement shall be appended to the decision, without other formality than verification of the authenticity of the decision, by the national authority which the government of each Member State shall designate for this purpose and shall make known to the Commission and to the Court of Justice of the European Union."

One of the specificities in carrying out the tasks of public administration of a Member State arising from European Union law is that the acts of application of law resulting from this activity may also have transnational effects, i.e. effects not only in the territory of the Member State that issued the act of application of law, but also in the territory of another (other) Member State(s), without that act having to be recognised in the territory of the Member State concerned, i.e. it has an automatic effect (Jakab, 2018, pp. 7-18). For example, if one Member State decides to issue a Schengen visa to a third-country national, the effects of such a decision will be applied in the territory of all Member States within the Schengen area. Similarly, a decision to grant a residence permission in the territory of one Member State, the granting of citizenship of one Member State (automatically resulting in the citizenship of the European Union), a decision to admit certain goods will have similar effects (see e.g. De Lucia, 2012, pp. 17-45; Seman, 2018, pp. 33-48; Ruffert, 2001, pp. 453-470; Handrlica, 2017a, pp. 82-113; Handrlica, 2017b, pp. 49-59; Handrlica, 2017c, pp. 63).

According to doctrine, transnational administrative acts can have different forms. The first form is the administrative act which produces "effect-related transnationality"; in this case an "administrative act is enacted in a state with regard to the addressee resident there, and which develops a legal effect beyond the borders of this state" (Ruffert, 2011, p. 281). In the second form the transnational character results from the fact that the issuing 
authority and the addressee of the administrative act are located in different states, i.e. this is "addressee-related transnationality" (Ruffert, 2011, p. 287). In the third form a foreign authority itself crosses the state border in order to issue an administrative act abroad, i.e. this is "authority-related transnationality (Ruffert, 2011, p. 290).

It can therefore be stated that the European Union had, and still has, a significant influence on the activities of public administration in the new Member States (but not only there) and on the tasks which they carry out.

\section{Influence of European Union law on processes in public administration}

Processes in public administration of its Member States are another area influenced by the European Union and its law. This influence is manifested from two perspectives. First of all, in the form of general principles and provisions relating to all processes in public administration. ${ }^{6}$ In addition, it is also manifested in the form of specific provisions regulating specific procedures or specific areas.

In connection with the general principles and provisions, the influence of the European Union is evident both from the texts of law and from the results of the decisionmaking activities of the Court of Justice of the European Union. One of the most relevant documents in this respect is the Charter of Fundamental Rights of the European Union, which became binding in 2009 when the Treaty of Lisbon entered into force. Article 41 of the Charter proclaims the right to good administration. According to that Article, "Every person has the right to have his or her affairs handled impartially, fairly and within a reasonable time by the institutions and bodies of the Union". This right includes the right of every person to be heard, to have access to his or her file, the right to be given reasons for decisions of the administration, the right to have the administration to make good any damage, and the right to use a chosen language of the Union. This right to good administration can also be exercised in relation to the authorities of a Member State if they apply European Union law (see Nehl, 2009, p. 322; Benko, 2013, pp. 1651-1667).

Before this right was expressed in the Charter, these principles had been recognised by both European and national courts, pointing out the common constitutional heritage of all Member States. Some of these principles were also declared by the European Court of Human Rights, referring to Article 6 of the European Convention for the Protection of Human Rights and Fundamental Freedoms, i.e. to the provision governing the right to a fair trial, ${ }^{7}$ or also to other provisions of that Convention (Mattarella, 2011, p. 65).

These general principles are not only provided for in the national legislation of individual Member States governing general administrative processes, but also in international treaties or internal regulations of several international or global organisations. They

\footnotetext{
6 See also OECD, 1999.

For example, Taskin and others v. Turkey, No. 46117/99.
} 
commit themselves to respect these principles, but also require their members to respect them in administrative processes. ${ }^{8}$

It should be pointed out that these general principles are applicable in both regulatory and application processes. Certainly, the rules relating to a fair trial have a wider impact in the regulatory processes. On the other hand, the right to have access to the file or the right to be given reasons for decisions are more significant in the application processes. In any case, all these general principles are to be established in the administration of each Member State, also in order to create a single administrative area.

In addition to the general principles and provisions, the European Union influences the processes of national public administration by establishing specific procedural rules for their action. The most notable processes influenced by the European Union are processes relating to the protection of the environment - environmental impact assessment or integrated permitting of activities polluting the environment. In addition, public procurement processes as well as financial control processes are also significantly influenced by European Union law. It is not the purpose of this paper to analyse these procedures in more detail; rather, its purpose is to point out the most important processes influenced by European Union law.

The basic acts of the European Union regulating the environmental impact assessment process are Directive 2001/42/EC of the European Parliament and of the Council of 27 June 2001 on the assessment of the effects of certain plans and programmes on the environment and Directive 2011/92/EU of the European Parliament and of the Council of 13 December 2011 on the assessment of the effects of certain public and private projects on the environment. The intention pursued by these directives has been implemented in the laws of all new Member States in the form of national legislation. ${ }^{9}$ The environmental impact assessment procedure is a procedure of expert and public assessment of the envisaged environmental impacts of strategic documents during their development and prior to their authorisation, as well as the proposed activities before deciding on their location or prior to their authorisation under specific regulations (see Sčensná \& Vernarský, 2016, p. 74).

The public procurement process of both contracting authorities and sectoral contracting entities has also been significantly influenced by Europeanisation. European legislation in this area has been subject to a number of changes. This issue is currently regulated in Directive 2014/24/EU of the European Parliament and of the Council of 26 February 2014 on public procurement and Directive 2014/25/EU of the European

\footnotetext{
The most common example in this respect is the Aarhus Convention of 1998.

9 For example, in the Slovak Republic through Act No. 24/2006 on environmental impact assessment, amending certain acts, as amended; in the Czech Republic through Act No. 100/2001 on environmental impact assessment, amending certain related acts (Environmental Impact Assessment Act); in the Republic of Poland through the Act on providing information on the environment and environmental protection, public participation in environmental protection and on environmental impact assessment; and in Hungary through Governmental Decree No. 151/2009 (VII. 23.) regarding the procedures of environmental impact assessment and the single procedure of authorisation of utilisation of the environment. (XII. 25).
} 
Parliament and of the Council of 26 February 2014 on procurement by entities operating in the water sector, energy, transport and postal services sectors. ${ }^{10}$

Last but not least, European Union law significantly influences the financial control and audit process. This is connected with to the need for the European Union to ensure that financial discipline is respected, in particular as regards the use of EU funds. The basic rules for financial control within the European Union are laid down in legal acts governing the Union's budgetary rules as well as that governing the individual funds from which finances are provided. Such basic acts include Regulation (EU, Euratom) 2018/1046 of the European Parliament and of the Council of 18 July 2018 on the financial rules applicable to the general budget of the Union, amending Regulations (EU) No 1296/2013, (EU) No 1301/2013, (EU) No 1303/2013, (EU) No 1304/2013, (EU) No 1309/2013, (EU) No 1316/2013, (EU) No 223/2014, (EU) No 283/2014 and Decision No 541/2014/EU and repealing Regulation (EU, Euratom) No 966/2012; and Regulation (EU) No 1303/2013 of the European Parliament and of the Council of 17 December 2013 laying down common provisions on the European Regional Development Fund, the European Social Fund, the Cohesion Fund, the European Agricultural Fund for Rural Development and the European Maritime and Fisheries Fund and laying down general provisions on the European Regional Development Fund, the European Social Fund, the Cohesion Fund and the European Maritime and Fisheries Fund and repealing Council Regulation (EC) No 1083/2006.

Taking into account the form of this legislation - i.e, regulation -, the effects of these legal acts on the public administration control and audit processes of the new Member States were direct and immediate (Tekeli, 2016, p. 85).

\section{Conclusion}

The membership of new Member States in the European Union, as well as the efforts for such membership, have also influenced the formation of the organisation of public administration, its activities as well as the processes taking place in the public administration of these countries. The intensity of this influence was different but still relevant in relation to these areas.

As regards the organisation of public administration in the new Member States, it should be noted that European Union law lays down the requirements for the creation of a sufficient framework of public administrative authorities to enable the effective implementation of European Union law. The individual secondary acts of Union law further specify this requirement in relation to a specific area regulated by a respective act. However, European Union law does not lay down any specific requirements for the organisation of public administration; it leaves them up to Member States. An exception to this statement

\footnotetext{
${ }_{10}$ The adoption of these Directives was also reflected in Slovak legislation through Act No. $343 / 2015$ on public procurement, amending certain acts, as amended; in Czech legislation through Act No. 134/2016 on public procurement; in Polish legislation through Act of 11 September 2011 (Public Procurement Act); and in Hungarian legislation through Act 2015 CXLIII on public procurement.
} 
is the Union's requirement for Member States to develop the so-called national regulatory authorities, which are to be independent of other authorities, and which have an independent budget and specific powers. This requirement is reflected in the organisation of public administration of new Member States in the extension of the category of state administration authorities with nationwide competence independent of central state administration authorities.

The European Union has also influence on the activities of public administration in the new Member States, i.e. on tasks which it carries out. The implementation of European Union law has also been added to the scope of national public administration tasks, particularly in the area of shared competence between the European Union and the Member States. The scope of these tasks is quite wide, and the purpose of this paper is not to provide its exhaustive enumeration. In addition to tasks of national public administration arising from the Union's acts of general application, tasks may also result from the individual acts of Union bodies, institutions or agencies. A specific feature of the implementation of European Union law is that a decision taken by a public administration of one Member State has an effect also in the territory of another Member State, several or all Member States.

Last but not least, the European Union has also had an influence on processes taking place in the public administration of Member States. This influence has been in two forms: in the form of the implementation of general procedural principles or provisions, and in the form of the need for adapting certain specific procedures. The latter category mainly concerns environmental protection processes - environmental impact assessment processes or integrated permitting of activities polluting the environment. This also applies to public procurement procedures for both contracting authorities and sectoral contracting entities. An example of this influence is the financial control and audit process, which is also influenced by the requirements of the European Union.

It can therefore be stated that the public administration in the new Member States has been strongly influenced by European Union law; to the greatest extent in connection with activities in the implementation of European Union law, and to a less, but relevant extent, in connection with public administration procedures as well as with the organisation of public administration.

\section{References:}

Addink, H. (2005). Good Governance: Lessons from Administrative Law. In Curtin, D.M. \& Wessel, R.A. (Eds.), Good Governance and the European Union. Reflections on Concepts, Institutions and Substance (pp. 21-43). Intersentia nv, Ius Commune reeks, vol. 49,

Benko, R. (2013). Extending the scope of application of the EU Charter of Fundamental rights on the basis of the Court of Justice case law on European citizenship. In Days of Law 2012: part VIII. Právo Evropské unie po Lisabonu (pp. 1651-1667). Evropská unie a mezinárodní právo, Brno: Masaryk University.

Brusis, M. (2002). Visegrad countries in an enlarged trans-Atlantic community. Dearborn: Institute for Public Affairs.

De Lucia, L. (2012). Administrative Pluralism, Horizontal Cooperation and Transnational Administrative Acts. Review of European Administrative Law, 5(2), pp. 17-45. 
Füle, Š. (2013). Copenhagen criteria. The Backbone of EU Enlargement. The Copenhagen criteria and the Enlargement of the European Union. 20 Years that changed Europe [Conference report]. www.hm.dk/ documents/20\%20Years\%20that\%20Changed\%20Europe\%20.pdf

Handrlica, J. (2017a). Inter-administrative tie of administrative acts in the EU law. Societas et Iuurisprudentia, 5(3), pp. 82-113.

Handrlica, J. (2017b). Selected problems associated with the application of the model of transterritorial administrative acts. Studia Iuridica Cassoviensia, volume 5.2017, No, 2, pp. 49-59.

Handrlica, J. (2017c). Vybrané problémy spojené s aplikací modelu transteritoriálních správních aktů [Transterritorial administrative acts. Studies in international administrative law]. Praha: Národohospodářsky ústav Josefa Hlávky.

Heidbreder, E. G., \& Brandsma, G. J. (2017). The EU Policy Process. In Ongaro, E. \& Thiel, S. V. (Eds.), The Palgrave Handbook of Public Administration and Management in Europe (pp. 805-821). London: Springer.

Hofmann, H. C. H, Rowe, G. C., \& Türk, A. H. (2011). Administrative Law and Policy of the European Union. Oxford: Oxford University Press.

Jakab, R. (2010). Public-Law regulation of Comparative Advertising. Košice: Pavol Jozef Šafárik University.

Jakab, R. (2016). Vplyv Európskej únie na organizáciu, činnost' a procesy vo verejnej správe [The influence of the European Union on the organization, activities and processes in public administration]. In Krunková, A. (Ed.), Európska Únia a jej vplyv na organizáciu a fungovanie verejnej správy v Slovenskej republike. Perspektívy a Odpovede na výzvy spojené s predsedníctvom Slovenskej republiky v Rade Európskej únie [The European Union and its influence on the organization and functioning of public administration in the Slovak Republic. Perspectives and Responses to the Challenges Associated with the Presidency of the Slovak Republic in the Council of the European Union] (pp. 11-21). Košice: Pavol Jozef Šafárik University.

Jakab, R. (2018). Extrateritorialita a transteritorialita v podmienkách EÚ a jej členských štátov [Extraterritoriality and trans-territoriality in the conditions of the EU and its Member States]. In Jakab, R. (Ed.), Extrateritoriálne účinky činnosti orgánov verejnej moci [Extraterritorial effects of the activity of public authorities] (pp. 7-18). Košice: Pavol Jozef Šafárik University.

Jánošíková, M. (2013). Repetitórium práva Európskej únie [Repetitorium of European Union law]. Bratislava: Iuris Libri.

Konstadinides, T. (2009). Division of Powers in European Union Law: The Delimitation of Internal Competence Between the EU and the Member States. Kluwer Law International B.V.

Košičiarová, S. (2012). Princípy dobrej verejnej správy a Rada Európy [Principles of good governance and the Council of Europe]. Bratislava: Wolter Kluwer.

Mattarella, B. G. (2011). The Influence of European and Global Administrative Law on National Administrative Acts. in Chiti, C. E., \& Mattarella, B. G. (Eds.), Global Administrative Law and EU Administrative Law. Relationships, Legal issues and Comparison (pp. 61-85). Heidelberg: Springer-Verlag Berlin. https://doi. org/ 10.1007/978-3-642-20264-3_4

Nehl, H. P. (2009). Good administration as procedural right and/or general principle? In Herwig, C. H., Hofmann, H. C. H., \& Türk, A. (Eds.), Legal challenges in EU administrative law (pp. 322-351). Cheltenham: Edward Elgar Publishing Limited. https://doi.org/10.4337/9781848449206.00020

OECD (1999). European Principles for Public Administration. SIGMA Papers 27, OECD Publishing.

Pekár, B. (2012). Európske správne právo a európsky správny priestor [European administrative law and European administrative space]. Bratislava: EUROIURIS - Európske právne centrum [European legal centrum].

Ruffert, M (2001). Der transnationale Verwaltungsakt. Die Verwaltung, 34, pp. 453-470.

Ruffert, M. (2011). The transnational Administrative Act. In Jansen, O. J. \& Schöndorf-Haubold, B. (Eds.), The European Composite Administration (pp. 277-290). Intersentia. 
Sčensná, A., \& Vernarský, M. (2016). Zainteresovaná verejnosta ako účastník povol'ovacích konaní na úseku ochrany životného prostredia - slovenské reálie [Interested public as a participant in permitting procedures in the field of environmental protection - Slovak realities]. In Krunková, A. (Ed.), Európska únia a jej vplyv na organizáciu a fungovanie verejnej správy v Slovenskej republike - doterajší vývoj, aktuálny stav, perspektívy [The European Union and its influence on the organisation and functioning of public administration in the Slovak Republic - current development, current state, perspectives] (pp. 74-86). Košice: Pavol Jozef Šafárik University.

Schweiger, Ch., \& Visvizi, A. (2018). Central and Eastern Europe in the EU: Challenges and Perspectives Under Crisis Conditions. Routledge: Routledge Studies in the European Economy. https://doi.org/10.4324 19781315230986

Seman, T. (2018). Pojem a účinky transteritoriálnych aktov orgánov verejnej správy [The concept and effects of trans-territorial acts of public administration bodies]. In Jakab, R. (Ed.), Extrateritoriálne účinky činnosti orgánov verejnej moci [Extraterritorial effects of the activity of public authorities] (pp. 33-48). Košice: Pavol Jozef Šafárik University.

Sobihard, J. (2007). Administrative Code. Commentary. Bratislava: Wolters Kluwer.

Tekeli, J. (2016). Vplyv Európskej legislatívy na procesný systém finančnej kontroly v obecnej samospráve [The impact of European legislation on the procedural system of financial control in municipal self-government]. In Krunková, A. (Ed.), Európska únia a jej vplyv na organizáciu a fungovanie verejnej správy v Slovenskej republike - doterajší vývoj, aktuálny stav, perspektívy [The European Union and its influence on the organization and functioning of public administration in the Slovak Republic - current development, current state, perspectives] (pp. 87-96). Košice: Pavol Jozef Šafárik University.

Zervoyianni, A., Argiros, G., \& Agiomirgianakis, G. (2006). European Integration. Hampshire: Palgrave Macmillan.

\section{Legal sources}

Treaty on European Union.

Treaty on the Functioning of the European Union.

Directive No 2006/114/ES the European Parliament and of the Council of 12 December 2006 concerning misleading and comparative advertising.

Directive No 2002/21/EC of the European Parliament and of the Council of 7 March 2002 on a common regulatory framework for electronic communications networks and services (Framework Directive).

Regulation (EU) 2016/679 of the European Parliament and of the Council of 27 April 2016 on the protection of natural persons with regard to the processing of personal data and on the free movement of such data, and repealing Directive 95/46/EC (General Data Protection Regulation). 